\title{
FOSTERING STUDENT PARTICIPATION THROUGH INTERACTIVE TEACHING IN BASIC ENGLISH CLASS
}

\author{
Siane Indriani \\ siane.indriani@uph.edu \\ Universitas Pelita Harapan- Lippo Karawaci
}

\begin{abstract}
The purpose of the study was to examine the $1^{\text {st }}$ semester teacher college students' perceptions of the interaction between them and their teacher in Basic English class through class discussion interactive teaching in Basic English class. To create a successful and effective teaching, cooperation between teacher and students is needed. An effective teacher must be able to present their material, effectively manage their classroom according to the lesson they've planned, accommodate their students' needs, and enhance their students' participation in the learning activities. Participants were 25 students who reported their perceptions on the interactive teaching in addition to their learning process. Result suggested that the interactive teaching fostered student participation during the learning activities. Teaching method such as class discussion that involved the whole class participation to raise questions and discuss about the answer or solution would require interaction between teacher and students more intensively. This interactive teaching method could be implemented for college students, especially because they were expected to participate more actively in the learning activities and become more independent learners. This study could also be an alternative for any educational practitioners who would like to foster their students' participation.
\end{abstract}

Keywords: interactive teaching, student participation, interaction

\begin{abstract}
ABSTRAK
Tujuan penelitian ini adalah untuk mempelajari secara mendalam mengenai persepsi siswa tentang interaksi antara guru dan siswa di kelas melalui pengajaran interaktif di kelas Bahasa Inggris Dasar. Agar pembelajaran sukses dan efektif, diperlukan kerjasama antara guru dan siswa. Seorang guru yang efektif harus mampu menyajikan materi, secara efektif mengelola kelas sesuai dengan pembelajaran yang telah direncanakan, mengakomodasi kebutuhan siswa, dan meningkatkan partisipasi siswa dalam kegiatan pembelajaran. Terdapat 25 siswa yang melaporkan persepsi mereka pada pengajaran interaktif yang berlangsung selama proses belajar mereka. Hasilnya menyatakan bahwa pengajaran
\end{abstract}


interaktif meningkatkan partisipasi siswa selama kegiatan belajar. Metode pengajaran seperti diskusi kelas yang melibatkan partisipasi seluruh kelas untuk mengajukan pertanyaan dan membahas tentang jawaban atau solusi membutuhkan interaksi antara guru dan siswa lebih intensif. Metode pengajaran interaktif ini dapat diterapkan untuk mahasiswa, terutama karena mereka diharapkan untuk berpartisipasi lebih aktif dalam kegiatan pembelajaran dan menjadi pelajar yang lebih mandiri. Studi ini juga bisa menjadi alternatif bagi setiap praktisi pendidikan yang ingin mendorong partisipasi siswa mereka di dalam proses pembelajaran.

Kata kunci: pengajaran interaktif, partisipasi siswa, interaksi

\section{INTRODUCTION}

Teaching is a rewarding profession and a challenging calling at the same time. It gives a teacher both an opportunity to enrich the lives of students in so many ways, including well-planned, creative and interactive teaching and to provide guidance for troublesome experiences for students during the learning process. Maarof (2007) and Cobb (1999) said that the attributes of teacher quality that included possessing pedagogical knowledge, subject content knowledge, skills, and attitudes are necessary for effective teaching, strong sense of ethics, and capacity for renewal and ongoing learning. Expository teaching method combined with questioning technique are two ways that can be used to promote students' participation. Discussion is another alternative way that relatively opens more communication of ideas by all participants during the teaching and learning process. Teachers need to give opportunity for students to share their ideas and students need to give response on what their teachers ask. Students' participation during the learning process often relies on the interaction between student-teacher and student with other students (Marsh, 2004: 156).

\section{LITERATURE REVIEW}

\section{Students' Participation}

Quoted from Howard, Clark, and Short (1996), Linda Marie Fritschner in her journal 'Inside the Undergraduate College Classroom: Faculty and Students Differ on the Meaning of Student Participation' said that the sources of interactions were classified as a) Teacher initiated (the teacher invites students to give comments or questions), b) Student initiated (the students interrupts the teacher without invitation to do so, in order to 
make comments or give questions), c) Direct question (the teacher calls on particular students to answer a question or make a comment), d) Offhand comments (student remarks that were loud enough to be heard by the class but did not pertain to the topic being discussed) (Fritschner, 2000: 334).

The study expected interaction between the students and the teacher to happen in such a way where students are actively engaged in the learning process. Student participation is considered as an active engagement process of a student (Rocca, 2009: 22). Student participation can be also defined as a consistent involvement of student's mind with the learning (Robert Wandberg, John Rower, 2003: 51). So, it is concluded that student participation involves the process of an active and consistent engagement of a student and his or her friends with the learning process. Student participation has many benefits which some of them are to provide feedback for students' learning process, to balance what is contributing in class and how much participation helps teachers control how much they talk, and to encourage dialogues between teacher-students or among students. The acts of asking questions, giving opinions or answers towards the questions posed by the teacher or fellow students are expected in the Basic English class where the study took place.

\section{Interactive Teaching}

An effective teaching happens when a teacher does not only prepare and present the learning materials as planned with a lecturing style, but it should go beyond that. It should open opportunities for both teachers and students to interact each other, sharing their thoughts, ideas, perspectives toward things discussed. Many researchers agree that interaction between the participants in the classroom plays $n$ important role to create a positive and supportive learning atmosphere (Muijs, Daniel \& David Reynolds, 2008, p. 65). How important a teacher while he is delivering the learning materials in such a way where students take accountable to show their best performance is another thing that will need attention. When a teacher dominates the learning process, it will not only hold up the students' responsibility to own their learning, but it will also shatter the students' inquiry and critical thinking skill. Therefore, how a teacher builds up the interaction and continuous communication with the students will influence how the learning process promotes the students' success.

Communication is the basis for all human interaction. Turney (1992) defines communication as "the sharing of messages or attitudes that produce 
a degree of understanding between a sender and a receiver. In the classroom, it involves exchanging information constantly as the process involving a number of persons receiving and sending messages. The classroom teacher often has to communicate regularly with a wide range of persons, each with different backgrounds and interests.

\section{FINDINGS AND DISCUSSION}

This study aims to see how the interaction between the teacher and students and how the students participate during the learning process where lecturing style is mixed with questioning and class discussion methods where students get a bigger chance to explore and share their ideas with other students in the class. The acts of asking questions, giving opinions or answers towards the questions posed by the teacher or fellow students are included in students' participation expected in the Basic English class where the study took place. The 25 students were required to get involved in giving responses toward the teacher's lecturing and listen to one another when it comes to discussion or recitation connected to the lecture.

The interactive teaching held in the class with teacher initiatively created a positive and supportive learning atmosphere by providing opportunities for both teachers and students to interact each other, sharing their thoughts, ideas, perspectives toward topics discussed. It was compelled by using a combined lecturing method with questions and discussions where In this study, the teacher delivered the materials about tenses to the students directly during the lecturing time. Then, the teacher invited the students to raise questions or give comments about tenses they had learnt. The teacher gave chance for the students to get more exposure on examples of tenses used in English sentences and have them to practice communicating with their partners with simple tenses. They would also be given grammatical problems that they need to discuss with their friends in their group that will be shared to the whole class later. By having more exposure in the target language in a more interactive way, it was expected that the students would gradually own their learning and be more confident to use English as a means of daily communication. They were encouraged to practice using English while they were discussing with their group members. The more they used English during the discussion, the more confident they would be when they needed to use English in a wider context. Basically, the interactive teaching held in the class was similar to the questioning technique 
used in any other English program which commonly emphasized on speaking sessions to enhance the participants' speaking skills. Unfortunately the fact was not that simple. It was a difficult task for teacher to ask students to participate enthusiastically regarding to their difficulty in using English grammatically correct. Students' participation during the learning process often relies on the interaction between student-teacher and student with other students (Marsh, 2004, p. 156). Therefore, interaction was maintained throughout the whole learning process, from the beginning until the end of the learning process. The interaction between teacher and students happened during the lesson delivery, question and answer session, and it continued with discussion where students could interact with their peers, sharing their ideas and support each other. The study aimed to find out how interactive teaching that involved lecturing, questioning and a class discussion fostered the students' participation in sharing their ideas, asking questions, giving responses toward the teacher's or other students' questions during the learning process.

The data were gathered using questionnaire, reflective journal made by each student, and interview conducted to get confirmation on certain items related to students' participation in the learning process. The learning objectives were to get participation from the students in asking questions or giving responses toward the teacher's or other students' questions and sharing their ideas to the whole class. Based on the questionnaire, it was found that there were only $40 \%$ of the students confidently raised questions to the teacher during the lecturing time. Based on the reflective journal, it was found that they were afraid of making mistakes in grammar used when they asked questions, they were not confident enough to speak in English, they would just wait for the questions raised by other students and listen to the answers from the teacher. These results were also in line with what the result from the interview. 50\% of the students said that they were not confident in asking questions using English that is not used in daily communication. They still needed to try their best to speak up and ask questions confidently to the teacher.

"I don't know what to ask. I am also still struggling with my English, so I am hesitate to ask questions. "

"My friends have asked the question that I actually would want to ask too."

"I don't know how to ask question properly in English with the correct grammar. I haven't used to use it daily either" 
Based on the results, it could be concluded that the major concern for the English learners were their personal fears or feeling inadequate in front of others as mentioned by Rocca $(2008-2009,23)$. However if the students believe that their ideas to be important and worthwhile or if they are interested in the topic discussed, they are more likely to contribute to class discussion. This would help them to be more comfortable using English as daily communication at least with their friends in the class.

Another result from the interview showed that students were less likely to participate in the learning activities if their teachers did not pay attention on their needs or difficulties. The teacher's approach and personality have considerable influenced on how students participate in teaching and learning process. Through the study on student participation at a University in Malaysia, it was said that the size of a classroom, personalities of the instructor (teacher) and students and the perception of peers influenced the students to participate in the class (Mohd. Yusof Abdullah, Noor Rahamah Abu Bakar \& Maitzul Haizan Mahbob, 2012, 516). From the questionnaire, $85 \%$ of the students said that the teacher has given opportunities and encouraged students to participate more in the learning process by asking questions with a simple grammar and appropriate intonation. In the students' reflective journal, they said that they were happy when the teacher could understand their needs and their difficulties as well. Here are examples of what the students said about the teacher's approach and personality:

"I feel so happy in this class because the teacher pays attention on our needs and also our difficulties in learning English. We can learn more about English easier."

"The teacher encourages us to speak in English, but she does not force us to do so. I like the way she teaches us."

"I hope I can improve my English soon and build my confidence upon it. I know learning English is hard, but I need to keep on trying! I need to practice it!"

"The teacher has tried the best she could to motivate us to speak up, but I am still not too confident to speak in front of the class."

"My teacher said as long as I keep on trying, God will help me all the way to reach my goal. I believe it! Thank you, Ms for helping me to learn English and know that God is with me all the way my learning process." 
So, most of the students agreed that the teacher had tried to build connection by understanding the students' need and difficulties and the way she taught has been able to help students to see their weaknesses and try to maximize their learning. There were still $15 \%$ said that the teacher should give more time for the students to interact more within a small group, so that they could practice speaking in English with the correct grammar with their friends more often. Interaction during the learning process which is impacted by classroom management, behavior management, direct teaching, varied teaching, interactive teaching, individual practice, and classroom climate should point to the rapport between teacher and students is very positive, the phase is brisk and activities varied, students respond promptly and confidently to opportunities to collaborate, solve problems and present ideas to their peers (Ko, James, Pamela Sammons, and Linda Bakkum, 2013).

\section{CONCLUSION}

During the teaching and learning process, the students who have been confident enough to speak English will be more independent and appreciate every opportunity given to them to enhance their English skill, especially in sharing their ideas, raising questions, giving responses toward the teacher's question or other students' questions.

Teacher's role is crucial in supporting the students' confidence to raise questions, give responses or answers from the questions given by the teacher or other students in English through interactive teaching that involve discussion among students. For a particular case when students are reluctant speaking up using English, teacher needs to give more time for students to work in a small group where they can practice their English with their group members first, then gradually feeling more confident to share their ideas with the whole class. Teacher should create more space where interaction occurs in order to promote students' participation during the learning process. Teacher's approach toward the students' need is important to support the students who are less confident in using English. Teacher's readiness to face any challenges in order to promote the students' success and the right heart to serve the students and help them to transform their mindset that God has entrusted them will really support the students' learning process.

Regarding to many challenges faced by teacher in modifying the lecturing method with questioning and discussion to promote the students' participation, there are some practical tips that might be helpful described below. 
1. Teacher needs to start every session with a smile and words of encouragement. This will bring a supportive learning atmosphere for students to start stepping out from their comfort zones and do things they do not usually do.

2. Teacher will need to make a strategic plan in arranging the questions based on the students' needs with different level of difficulty.

3. Teacher can assign students to be group leaders. It will build up the leadership skill within every student chosen to be the leaders.

Based on the research findings, it is suggested to have a further research on how peers influence students' self esteem needed to improve their participation in English class. In order to make students involved in the learning process, the learning strategies should accommodate the students to get involved cognitively, but also behaviorally engaged.

\section{REFERENCES}

Boyd, Robert D., and Myers, J. Gordon.1988. "Transformative education." International Journal of Lifelong Education 7 (4): 261-284.

Cranton, P. 1996. Professional development as transformative learning: new perspectives for teachers of adults. San Francisco, CA: Jossey-Bass Inc.

Fletcher, S. 2007. Mentoring adult learners: realizing possible selves. In M. Rossiter (Ed.), Possible selves and adult learning: perspectives and potential. New directions for adult and continuing education, 114, 7586). San Francisco: Jossey-Bass.

Marsh, Collin. 2004. Becoming a teacher. knowledge,skill, Issues, 3. Australia: Pearson Education Australia

Muijs, Daniel \& David Reynolds. 2008. Effective Teaching: theory and application, 2. London: Sage Publications, Ltd.

Robert Wandberg, John Rohwer. 2003. Teaching to the standards of affective practice: a guide to becoming a successful teacher. USA: Pearson Education, Inc., Retrieved February 2015

Rocca, K. A. 2009. Participation in the college classroom: the impact of instructor immediacy and verbal agression. Journal of Classroom Interaction.

Turney, C., Hatton, N, Laws, K., Sinclair, K. \& Smith, D. 1992. The classroom manager. Sydney: Allen \& Unwin 